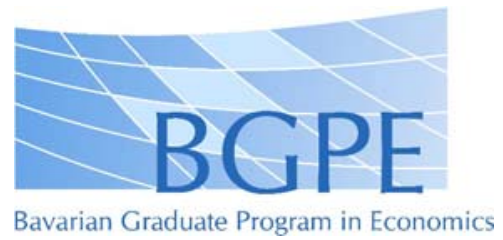

BGPE Discussion Paper

No. 52

\title{
Unionisation triggers tax incentives to attract foreign direct investment
}

\author{
Andreas Haufler \\ Ferdinand Mittermaier
}

May 2008

ISSN 1863-5733

Editor: Prof. Regina T. Riphahn, Ph.D.

Friedrich-Alexander-University Erlangen-Nuremberg

(c) Andreas Haufler, Ferdinand Mittermaier 


\title{
Unionisation triggers tax incentives to attract foreign direct investment*
}

\author{
Andreas Haufler ${ }^{\dagger}$ \\ University of Munich and CESifo
}

Ferdinand Mittermaier

University of Munich

\section{May 2008}

\begin{abstract}
This paper analyses tax competition between a unionised and a non-unionised country for the location of an outside firm. We show that unionisation offers an extra incentive for the government to attract a foreign competitor to a concentrated domestic market, in order to affect the behaviour of the domestic union. This results in the unionised country's government offering a tax discount (or a subsidy premium) to the outside firm in excess of what is needed to compensate the investor for the higher union wage. In equilibrium, therefore, the unionised country can attract the outside firm even if it has other location disadvantages, such as a smaller home market.
\end{abstract}

Keywords: tax competition, trade unions, foreign direct investment JEL Classification: H25, H73, J58

* Paper presented at conferences and seminars in Nottingham and Tilburg. We thank Jan Boone, Ron Davies, Clemens Fuest, Harry Huizinga, Arijit Mukherjee, Michael Pflüger, Nadine Riedel and Ian Wooton for helpful comments and Marcus Strobel for competent research assistance.

${ }^{\dagger}$ Seminar for Economic Policy, Akademiestr. 1/II, D-80799 Munich. Phone: +49-89-2180-3858, e-mail: Andreas.Haufler@lrz.uni-muenchen.de

${ }^{\ddagger}$ Seminar for Economic Policy, Akademiestr. 1/II, D-80799 Munich. Phone: +49-89-2180-6752, e-mail: mittermaier@lrz.uni-muenchen.de 


\section{Introduction}

In most OECD countries, as well as in many developing countries, the potential benefits from foreign direct investment (FDI) in the form of higher employment, intensified competition in product markets, and positive productivity spillovers on other sectors of the economy are increasingly perceived by policy makers. The employment argument, in particular, has become a highly important one. In many OECD countries employment in multinational firms now accounts for more than $25 \%$ of total employment in the manufacturing sector. ${ }^{1}$ At the same time, multinational firms are able to choose among an increasing number of potential investment locations, particularly in Eastern Europe and Southeast Asia, which offer low wages, an educated workforce, and rapidly expanding domestic markets. This has led to a number of highly publicised cases of plant relocations from rich OECD countries to lower-cost regions. A recent example is the telecommunications firm Nokia, which announced the closure of its production unit in the German city of Bochum in early 2008 while at the same time opening up a new production plant in Romania.

As a result of these developments the competition among potential host countries to attract internationally mobile firms has tightened visibly during the last decades. This can be seen in the corporate tax changes, in particular the reductions of statutory tax rates, that many countries have undertaken since the 1980s (see Devereux et al., 2002). A second and even more direct indicator is the increasing use of direct location subsidies that are paid to foreign firms. Table 1 lists 22 cases for the period from 2001 to 2007 where substantial investment subsidies (above Euro 20 million) have been offered by host countries and approved by the European Commission. These subsidies often account for up to $30 \%$ of the present value of the investment, and in some cases for

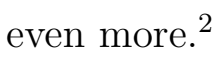

A striking fact in Table 1 is that the highest subsidies are paid for firms that engage

\footnotetext{
${ }^{1}$ In 2005, employment in multinational firms as a percentage of total manufacturing employment was, for example, $33.1 \%$ in Belgium, $26.4 \%$ in France, $15.2 \%$ in Germany, $48.0 \%$ in Ireland, $33.8 \%$ in Sweden, $27.6 \%$ in the United Kingdom and $11.2 \%$ in the United States. See OECD (2008).

${ }^{2}$ Note that the subsidy payments collected in Table 1 cover only direct monetary transfers and thus represent merely a lower bound for the overall value of the incentive package. The latter often includes additional measures, such as the free provision of public infrastructure.
} 
Table 1: Approved investment subsidies in EU member states (2001-2007)

\begin{tabular}{|l|c|l|c|c|}
\hline Company (sector) & $\begin{array}{c}\text { Date of } \\
\text { approval }\end{array}$ & $\begin{array}{l}\text { Host country } \\
\text { (city/region) }\end{array}$ & $\begin{array}{c}\text { State aid } \\
\text { (million } € \text { ) }\end{array}$ & $\begin{array}{c}\text { Aid inten- } \\
\text { sity }(\%)^{a}\end{array}$ \\
\hline \hline Nissan & $01 / 2001$ & U.K. (Sunderland) & $60^{b}$ & 18.6 \\
Volkswagen & $07 / 2001$ & Germany (Dresden) & 75 & 12.3 \\
Daimler Chrysler & $12 / 2001$ & Germany (Thuringia) & 57 & 30.9 \\
Infineon (semiconductors) & $04 / 2002$ & Germany (Saxony) & 219 & 19.8 \\
ST Microelectronics & $04 / 2002$ & Italy (Sicily) & 542 & 26.3 \\
Iveco (utility vehicles) & $10 / 2002$ & Italy (Puglia) & 109 & 44.0 \\
BMW & $12 / 2002$ & Germany (Leipzig) & 363 & 30.1 \\
Solar World (solar cells) & $03 / 2003$ & Germany (Saxony) & 33 & 35.0 \\
European Optic Media & $06 / 2003$ & Germany (Thuringia) & 35 & 35.0 \\
Volkswagen & $06 / 2003$ & Spain (Navarra) & 20 & 6.4 \\
Ford & $07 / 2003$ & Belgium (Genk) & 45 & 4.2 \\
AMD (microelectronics) & $02 / 2004$ & Germany (Saxony) & $545^{c}$ & $22.7^{c}$ \\
Wacker (silicon wafers) & $02 / 2004$ & Germany (Saxony) & 120 & 28.0 \\
Infineon (semiconductors) & $03 / 2004$ & Portugal (Porto) & 42 & 29.0 \\
DHL Airways (logistics) & $04 / 2004$ & Germany (Leipzig) & 70 & 28.0 \\
DOW PET (synthetics) & $04 / 2004$ & Germany (Saxony) & 28 & 23.4 \\
e-glass (glass) & $04 / 2004$ & Germany (Saxony-Anh.) & 42 & 35.0 \\
Peugeot Citroen & $09 / 2004$ & U.K. (Ryton) & $30^{b}$ & 9.8 \\
De Tomaso (vehicles) & $01 / 2005$ & Italy (Calabria) & 60.0 \\
Südzucker (bioethanol) & $06 / 2005$ & Germany (Saxony-Anh.) & 43 & 23.8 \\
AMD (microelectronics) & $07 / 2007$ & Germany (Saxony) & 11.9 \\
Kia Motors & $12 / 2007$ & Slovakia (Stredné Sl.) & 15.0 \\
\hline
\end{tabular}

${ }^{a}$ present value of state aid divided by present value of investment

${ }^{b} 1$ British Pound is converted to $1.5 € \quad{ }^{c}$ upper limit

Source: Official Journal of the European Communities, C and L (http://eur-lex.europa.eu) 
in regions characterised by weak economic activity and high unemployment, but simultaneously are part of countries with strong trade unions that succeed in keeping up wages even in low-productivity regions. This is true, in particular, for Eastern Germany and Southern Italy, where the collective bargaining coverage rate is above $80 \%$ of the workforce. ${ }^{3}$ This suggests that fiscal policies are used to compensate investors for the location disadvantages of facing high wages without benefitting from positive spillovers in an industrial core region. To some extent this reflects the European Union's regulations on state aid, which specify that location subsidies are only permitted to compensate investors for a demonstrated cost disadvantage in comparison to a feasible alternative location. The question remains, however, why unionised countries are also willing to provide high subsidies, the cost of which have to be fully borne by them. ${ }^{4}$

More generally, governments and trade unions in host countries face similar constraints in that wage increases and higher taxes may both lead to discontinuous losses of production when multinational firms threaten to relocate production to countries with lower gross-of-tax costs. It can thus be expected that these two players will respond to each other's policies to attract multinational firms, or to keep them in the country. Interestingly, this interdependence of the tax/subsidy decisions of governments and the wage policies of trade unions in the competition for FDI has so far received very little attention in the academic literature.

Our analysis aims, therefore, to study how the presence of a domestic union affects the incentives of governments to grant tax concessions, or even direct investment subsidies, in order to attract FDI. In particular, we will argue in this paper that investment

\footnotetext{
${ }^{3}$ In contrast, this coverage rate (the percentage of employees for whom the wage negotiated by the union is binding) is only around 50\% in the UK and well below 20\% in the USA (Cahuc and Zylberberg, 2004, p. 372). See also Freeman (2007) for an account of the differences in labour market institutions in the OECD and elsewhere.

${ }^{4} \mathrm{~A}$ further interesting question is why more than $80 \%$ of the subsidies to industry in the OECD take the form of investment subsidies, rather than direct subsidies to employment, even if their purpose is to counteract labour market rigidities (see Fuest and Huber, 2000, Table 1). One answer to this question is that employment subsidies may strengthen the position of trade unions, whereas investment subsidies can induce more competition in both product and labour markets. Fuest and Huber (2000) show, in a model where firms with different productivities bargain with unions over both wages and employment, that an investment subsidy financed by a labour tax increases the number of active firms and generates welfare gains by reducing the rents of workers.
} 
subsidies can be used to affect the policy of trade unions, offering them more incentives to exert wage restraint in exchange for higher employment. We develop this result in a model where a unionised and a non-unionised country, which additionally differ in size, compete for the location of a single outside firm. We show that the government of the unionised country has a greater incentive to attract the foreign firm, in order to 'tame' the domestic union's wage demands. This results in the unionised country's government offering a tax discount (or a subsidy premium) to an outside firm in excess of what is needed to compensate the investor for the higher wages caused by union power. In equilibrium, therefore, the unionised country will be able to attract the FDI even if it has a further location disadvantage through a smaller home market.

Our analysis relates to two different strands in the literature. The first set of papers analyses tax competition for FDI in models of imperfectly competitive product markets and with various country asymmetries. This 'bidding-for-firms' literature was initiated by Black and Hoyt (1989), and it has since been applied to tax/subsidy competition between countries that differ in size (Haufler and Wooton, 1999), factor endowments (Davies, 2005), or the number of domestic competitors (Bjorvatn and Eckel, 2006). A general finding of this literature is that countries can tax the profits of an internationally mobile firm to the extent that they possess a location advantage, relative to their closest competitor. ${ }^{5}$ Related results have been derived in the 'new economic geography' literature where agglomeration effects and a larger market size give the core country a competitive advantage and allow it to tax positive location rents (see Kind et al., 2000; Baldwin and Krugman, 2004; Ottaviano and van Ypersele, 2005; Borck and Pflüger, 2006). None of these models, however, incorporates trade unions as an additional player in the competition for FDI.

A second and parallel strand in the literature has focused on the effects that unionisation has on foreign direct investment. ${ }^{6}$ Mezzetti and Dinopoulos (1991) investigate the role of unionisation in a firm's exporting versus FDI decision. As recently shown by

\footnotetext{
${ }^{5}$ Ferrett and Wooton (2005) show that when there are two internationally mobile firms, rather than only one, the taxing power of the competing countries is increased. Under some conditions they will even be able to extract all profits from the duopolistic firms.

${ }^{6}$ These contributions are part of a more general literature that analyses the interaction between unionisation, imperfect competition in goods markets, and economic integration. See e.g. Brander and Spencer (1988), Huizinga (1993), Driffill and van der Ploeg (1995), and Naylor (1998).
} 
Mukherjee (2008), these two modes of serving a foreign market may also be simultaneously chosen by a cost-minimising firm when labour markets are unionised. Leahy and Montagna (2000) analyse how foreign direct investment is affected by different degrees of wage setting centralisation. Naylor and Santoni (2003) show, among other results, that foreign direct investment is less likely in a given country the greater is its union's bargaining power. The same effect is also present in the economic geography model of Munch (2003). Lommerud et al. (2003) show that unionisation can induce foreign direct investment and lead to job losses in the unionised country and this scenario becomes more likely as economic integration proceeds. All these papers, however, consider only trade unions and firms while ignoring government tax policies.

In this paper we combine the decisions of firms, trade unions and governments in a tax competition setting where governments move first and are thus able to influence the policy of trade unions. Since unionisation emerges as a location disadvantage from the previous literature, one would expect that a country with stronger unions needs compensating location advantages, such as an agglomeration of industry, or a large market size, in order to attract FDI. This is indeed the outcome in the fair wage model of Egger and Seidel (2007), the only other paper we are aware of to combine unionisation and tax competition in a model with endogenous location decisions of mobile firms. ${ }^{7}$ In their model, however, the labour market distortion is exogenously given by the fair wage preferences of workers. We will show in this paper that results change fundamentally when the extent of the labour market distortion can be affected by government tax policy. It is then possible that the unionised country also offers the smaller home market, yet still attracts the outside firm through large investment subsidies.

The remainder of this paper is organised as follows. Section 2 describes the general set-up of the model. Section 3 deals with the location and output decisions of firms.

\footnotetext{
${ }^{7}$ Skaksen (2005) analyses the incentives for a single country to attract a foreign firm to a unionised market with a domestic incumbent. This model focuses on complementarities between the outputs produced by the incumbent and the mobile firm, however, and does not incorporate location competition between two potential host countries. There is also a small literature on tax and social policy competition when labour markets are unionised and capital is internationally mobile (see Lejour and Verbon, 1996 or Fuest and Huber, 1999). In this literature product markets are perfectly competitive and thus there are no distinct output and location decisions of individual firms.
} 
Section 4 analyses the wage policies pursued by the trade union. Section 5 turns to the tax and subsidy decisions of the two governments. Section 6 discusses the robustness of our results with respect to alternative model assumptions. Section 7 concludes.

\section{The model}

We consider a model of two countries $i \in\{A, B\}$ which compete for the entry of a firm from a third country $C$. There are two sectors in each of countries $A$ and $B$, an imperfectly competitive sector $x$ and a perfectly competitive numéraire sector $z$. Countries $A$ and $B$ differ in two respects. First the imperfectly competitive sector $x$ is unionised in country $A$, but not in country $B$. Second, the two countries are generally of different size. The population of countries $A$ and $B$ taken together is normalised to unity and is assumed to be immobile across countries. A share $n$ of the total population lives in country $A$, whereas $1-n$ residents live in country $B$. Prior to the potential entry of the outside firm, there is one active firm in the $x$ industry in each of countries $A$ and $B$. Let $a$ and $b$ denote the existing firms in $A$ and $B$, respectively, whereas $c$ is the potential entrant. Good $x$ is a homogeneous good so that the outputs of all firms operating in this industry are perfect substitutes.

The existence of an incumbent (immobile) domestic firm is central to our model, as it gives the union in country $A$ the option to receive a wage surplus from employment in this firm, should firm $c$ decide not to locate in country $A$. In the absence of such an outside option, the union in country $A$ holds no bargaining power towards country $A$ 's government. As a result, the equilibrium wage rate in country $A$ would be at the competitive level, and the union would become irrelevant. To maintain the symmetry between the two countries with respect to market structure, we assume that an incumbent firm in sector $x$ also exists in country $B$.

The resulting duopolistic market structure implies, however, a considerable increase in the complexity of our model. We deal with this by assuming, in the main part of our analysis, that countries $A$ and $B$ do not trade good $x$ with each other. This assumption enables us to maintain asymmetries between countries with respect to both market size and the degree of unionisation while keeping the analysis highly tractable. It is shown in the appendix, and discussed in more detail in Section 6, that the analysis is completely 
analogous and results are qualitatively unchanged, if costly trade is permitted between countries $A$ and $B$. Intuitively, in the absence of trade between $A$ and $B$, attracting the outside firm changes the host country's market structure for good $x$ from monopoly to duopoly. If trade is permitted instead, then all three firms compete in both markets. Nevertheless competition is more intense in the country where the foreign firm sets up production, because the presence of trade costs acts as an imperfect shield for the firms in one country from the competition with firms in the other country (see Horstmann and Markusen, 1992). This shield becomes more effective as trade costs rise. Assuming that trade costs for good $x$ are prohibitively high will thus simply act to maximise the differential impact that the entry of the foreign firm has on the market structure in the host country, as compared to its competing neighbour.

In production, wages are the only variable costs in both sectors. In the competitive numéraire sector, $1 / \bar{w}$ units of labour are needed in both countries to produce one unit of output. There are no restrictions on trade in good $z$ so that international arbitrage equalises the price for this good and hence the competitive wage rate in both countries at $\bar{w} \cdot{ }^{8}$ In sector $x$, one unit of capital is needed for each firm to produce any output. Once this fixed factor is installed, one unit of labour produces one unit of output. Hence, in each country the variable cost of producing good $x$ equals the going wage rate in this sector.

An important asymmetry in our model is that the imperfectly competitive sector $x$ is unionised in country $A$, but not in country $B$. Hence country $A$ 's wage rate in the $x$ industry is denoted by $w_{A}$ (and derived in Section 4 below), whereas country $B$ 's wage rate in this sector is at the competitive level $\bar{w}$. The going sector-specific wage rate has to be paid by both the local firm and the potential entrant $c$. We assume that the outside firm $c$ disposes of only one unit of capital and hence can set up at most one plant, either in country $A$ or in country $B$. For example, if the fixed production factor in sector $x$ is interpreted as entrepreneurial services, then the foreign-owned firm $c$ might have only one suitable manager to run a plant in one of the two countries.

On the demand side, the preferences of households are assumed to be identical for all

\footnotetext{
${ }^{8}$ The same mechanism ties together prices and wages in international trade models when trade costs for one of the goods, but not for the other, are parametrically varied and incorporate prohibitive levels. See Baldwin et al. (2003, pp. 16-20).
} 
consumers and across countries. Per-capita utility in each country is of the quasi-linear and quadratic form

$$
u_{i}=\alpha x_{i}-\frac{1}{2} \beta x_{i}^{2}+z_{i} \quad i \in\{A, B\} .
$$

Each household in both countries $i \in\{A, B\}$ supplies one unit of labour. As only sector $x$ in country $A$ is unionised, an endogenous fraction $s_{A}$ of country $A$ 's workforce will find employment in this sector at wage $w_{A}$. The remainder of country $A$ 's workforce is employed in the $z$ sector and earns the competitive wage $\bar{w}$. Workers in country $A$ are homogeneous and their allocation to the two sectors is not explicitly modelled. There are simply some 'lucky' workers who earn more than the competitive wage. Since the preferences of all workers are identical, we can focus on the average income earned in country $A$ for most of the analysis. In country $B$, all workers earn the same competitive wage $\bar{w}$.

To derive the country-specific budget constraints, we assume that in each country the profit income earned by the local firm is redistributed to the domestic workerconsumers in equal per-capita shares. Moreover, we assume that both governments dispose of lump-sum instruments in order to finance subsidies or, in case they are able to tax the outside firm $c$, redistribute tax proceeds. With these assumptions, the (average) per-capita budget constraints in the two countries are:

$$
\begin{gathered}
w_{A} s_{A}+\bar{w}\left(1-s_{A}\right)+\frac{\left(\pi_{a}+t_{A}\right)}{n}=z_{A}+p_{A} x_{A}, \\
\bar{w}+\frac{\left(\pi_{b}+t_{B}\right)}{1-n}=z_{B}+p_{B} x_{B} .
\end{gathered}
$$

Here $\pi_{j}$ denotes the profits of the local firms $j \in\{a, b\}, t_{i}$ are the tax revenues in country $i$ obtained from the outside firm $c$ (negative, if subsidies are paid) and $p_{i}$ is the consumer price of good $x$ in country $i$.

Maximising the representative consumer's utility function in each country, subject to the budget constraint, and aggregating over individuals gives the market demand functions for $\operatorname{good} x$ :

$$
X_{A}=\frac{n\left(\alpha-p_{A}\right)}{\beta} ; \quad X_{B}=\frac{(1-n)\left(\alpha-p_{B}\right)}{\beta} .
$$

These market demand functions are independent of the exogenous income components in (2), due to the quasi-linear utility function. 
In order to examine the impact of union power on tax competition for the outside firm, we model a three-stage game. In the first stage, the two competing governments simultaneously and non-cooperatively choose a lump-sum tax or subsidy on the entry of the outside firm, which represents either an 'entry fee' (in the case of a tax) or a 'welcome gift' (in the case of a subsidy). ${ }^{9}$ The objective of governments in stage one is to maximise the overall utility of their respective population. Whether the equilibrium tax on the entry of the outside firm is positive or negative depends on the interplay of two counteracting forces. On the one hand, the entry of the outside firm is the only way for each government to increase competition in sector $x$. On the other hand, admitting the outside firm $c$ to an imperfectly competitive industry implies that the industry's profits will be shared with foreigners.

In the second stage, the union in country $A$ chooses the wage rate that maximises the wage surplus of its workers, or equivalently the overall wage bill. The trade-off for the union is that attracting the outside firm increases local output in the unionised sector, but at the same time the union may have to moderate its wage, relative to what it would optimally charge the domestic monopolist. Finally, in the third stage, the foreign firm decides to enter either market $A$ or market $B$ (provided that net profits in this market are positive) and output levels are chosen by all firms.

The sequence of events underlying our analysis is motivated by two observations. First, as we have discussed in the introduction, multinational firms are becoming increasingly footloose and can easily relocate production, if gross-of-tax production costs in a given country make it unattractive to stay there. This implies that both governments and unions have to take into account the possibility of losing (or not attracting) the outside firm when making their decisions. Second, we interpret the government's policy variable in a wide sense, as a general policy stance towards increasing competition in local markets by way of attracting FDI. Such a policy is clearly of a more long-term nature than the periodic wage negotiations in which trade unions are engaged and implies that the government of country $A$ can strategically adjust its tax policy in order to affect the wage claims of the local union. In Section 6 we discuss how our results are affected by different assumptions with respect to the model's time structure.

\footnotetext{
${ }^{9}$ Assuming lump-sum instruments is analytically convenient, but it also captures the character of many real-world investment subsidies. See Table 1 in the introduction.
} 


\section{Stage three: The firms}

In the usual way, the model is solved by backward induction. Firms act last in our game, basing their decisions on the taxes and wages set by the other players. Firms $a$ and $b$, the domestic incumbents, will decide about their output quantities, taking account of the simultaneous decisions of the outside firm. Firm $c$ decides where to locate and then produces the same quantity in the chosen market as the respective incumbent firm, since it faces the same wage rate and hence cost of production. Firms observe market conditions according to (3) and maximise their profits. We assume that firms compete à la Cournot.

To derive equilibrium outputs we need to distinguish between two regimes, depending on whether firm $c$ locates in country $A$ (Regime $A$, or $R A$ for short) or in country $B$ $(R B)$. Let superscripts denote the country in which the outside firm locates (i.e., the regime), whereas subscripts denote the countries or firms, for which a given value is calculated. With this notation, production quantities in the two regimes are

$$
\begin{array}{llrl}
(R A): & x_{a}^{A}=x_{c}^{A}=\frac{n\left(\alpha-w_{A}\right)}{3 \beta}, & x_{b}^{A}=\frac{(1-n)(\alpha-\bar{w})}{2 \beta} ; \\
(R B): & x_{a}^{B}=\frac{n\left(\alpha-w_{A}\right)}{2 \beta}, & x_{b}^{B}=x_{c}^{B}=\frac{(1-n)(\alpha-\bar{w})}{3 \beta} .
\end{array}
$$

Using (3) and noting that demand for good $x$ must equal local supply in each country in the absence of trade yields equilibrium prices in the two regimes

$$
\begin{aligned}
& (R A): \quad p_{A}^{A}=\left(\alpha+2 w_{A}\right) / 3, \quad p_{B}^{A}=(\alpha+\bar{w}) / 2 \text {; } \\
& (R B): \quad p_{A}^{B}=\left(\alpha+w_{A}\right) / 2, \quad p_{B}^{B}=(\alpha+2 \bar{w}) / 3 .
\end{aligned}
$$

These prices lead to regime-specific profit levels of

$$
\begin{array}{ll}
(R A): & \pi_{a}^{A}=\pi_{c}^{A}=n\left(\alpha-w_{A}\right)^{2} /(9 \beta), \quad \pi_{b}^{A}=(1-n)(\alpha-\bar{w})^{2} /(4 \beta) \\
(R B): & \pi_{a}^{B}=n\left(\alpha-w_{A}\right)^{2} /(4 \beta), \quad \pi_{b}^{B}=\pi_{c}^{B}=(1-n)(\alpha-\bar{w})^{2} /(9 \beta) .
\end{array}
$$

Equations (5)-(6) show the effects of the location decision of the mobile firm $c$. Given that the incumbent firms $a$ and $b$ are assumed to be internationally immobile, the entry decision of firm $c$ changes the market conditions in its host country from monopoly to duopoly, reducing aggregate profits and increasing consumer surplus in this market. In country $A$, a further distributional consequence is that the $x$ sector will grow, giving 
more workers the opportunity to earn a wage above the competitive level. This effect will be important for the union's wage decision below.

Firm $c$ will be indifferent where to settle down when its net-of-tax profits are the same in the two countries. It is ex ante unclear which country will be the more attractive location for the outside firm, as markets are generally of different size and need not have the same wages and taxes. The general condition for $c$ being indifferent between locations $A$ and $B$ is:

$$
\pi_{c}^{A}-t_{A}=\pi_{c}^{B}-t_{B} \Longleftrightarrow \frac{n\left(\alpha-w_{A}\right)^{2}-(1-n)(\alpha-\bar{w})^{2}}{9 \beta}=t_{A}-t_{B}
$$

This equation can be solved for the maximum wage that the union in country $A$ can charge and still make the firm no worse off than if it settled in country $B$. We denote this wage by $w_{A}^{A}$ and adopt the convention that the firm will locate in country $A$ whenever it is indifferent between the two locations. ${ }^{10}$ This critical wage depends on the tax rates decided by both governments in the first stage:

$$
w_{A}^{A}=\alpha-\frac{\sqrt{n\left[9 \beta\left(t_{A}-t_{B}\right)+(1-n)(\alpha-\bar{w})^{2}\right]}}{n} .
$$

For $w_{A} \leq w_{A}^{A}$ the firm will settle in country $A$, whereas for $w_{A}>w_{A}^{A}$ it will locate in country $B$. The maximum wage that the outside firm $c$ is willing to pay in country $A$ falls when the tax rate in country $A$ is high or that in country $B$ is low, and it rises when the competitive wage $\bar{w}$ (which is to be paid in country $B$ ) is high. Finally, it is straightforward to show that $w_{A}^{A}$ is rising in $n$, as the outside firm will want to settle in the larger market, other things being equal.

\section{Stage two: The union}

There are two widely used models of trade union behaviour in labour economics, the monopoly union model (as a special case of the more general right-to-manage model) and the efficient bargaining model. Both of these models are able to explain some, but not all, of the stylised facts in labour markets (Oswald, 1993). In the more narrowly

\footnotetext{
${ }^{10}$ In addition, the outside firm $c$ must also make positive profits in its preferred location. We will show below that this is always the case in equilibrium.
} 
related literature on the interaction between unionisation and FDI, however, virtually all contributions employ the monopoly union model. This approach is a benchmark for wage determination with maximum union power, allowing firms only to adjust quantities optimally in a later stage of the game. Stated differently, the union chooses its optimal point on the firms' labour demand curve. We also adopt the monopoly union approach in this paper. One specific advantage of this model in our framework is that it eliminates the possibility of strategic behaviour on the part of the incumbent firm in country $A .{ }^{11}$ Even with the simple monopoly union model, the trade-off faced by the union is enriched in our analysis as wage restraint will not only increase the output of the incumbent firm, but it may also induce the outside firm $c$ to settle in the country, thus further expanding local production of good $x$.

The union's objective is to maximise the domestic wage surplus over the competitive wage bill. ${ }^{12}$ Denoting this wage surplus by $\Omega$ we get

$$
\max _{w_{A}} \Omega=n s_{A}\left(w_{A}-\bar{w}\right)=X_{A}\left(w_{A}-\bar{w}\right)
$$

where $s_{A}$ is the share of country $A$ 's population working in the $x$ sector and the last equality follows from the market clearing condition for good $x$. Again we have to derive the optimal union policy separately for the cases where the outside firm settles in country $A$ or in country $B$. We assume that the union is interested only in the nominal wage and neglects the effects of its wage setting behaviour on the output price in sector $x$. One motivation for this assumption is that the number of workers in the $x$ sector is small, relative to country $A$ 's overall population. Hence most of the output of good $x$ is consumed by workers in the numéraire sector $z$, whose well-being does not enter the objective function of the sector-specific union. Alternatively, it could be argued that the nominal wage is the relevant indicator by which the union's leaders measure the 'success' of their wage setting decision.

\footnotetext{
${ }^{11}$ Giving the incumbent firm some power to decide on the wage rate, as in an efficient bargaining model, would imply that firm $a$ faces the following trade-off. If the firm agrees to a higher local wage, its costs of production will rise, but at the same time the higher wage may prevent the entry of the outside firm. The additional effects arising in this more general setting of wage determination are interesting in their own right, but they are beyond the scope of the present analysis.

${ }^{12} \mathrm{It}$ is seen from equation (8) that this objective is equivalent to maximising the total wage bill. The latter is obtained by adding the constant term $n \bar{w}$ to the wage surplus expression.
} 
We start the analysis of the union's wage setting decision in Regime $B$. In this regime only the domestic incumbent produces good $x$ in country $A$ and total output is given by $X_{A}=x_{a}^{B}$ in (4). From (8), the wage rate that maximises the objective function of the union is then

$$
w_{A}^{B}=\frac{(\alpha+\bar{w})}{2},
$$

resulting in a wage surplus for the union in country $A$ equal to

$$
\Omega_{A}^{B}=\frac{n(\alpha-\bar{w})^{2}}{8 \beta}
$$

If firm $c$ settles instead in country $A$, the union cannot charge a higher wage than $w_{A}^{A}$, as given in (7). In this case the wage rate is thus bound from above by the condition to attract the outside firm. Let us assume for the moment that the upper bound (7) is indeed binding and hence the union will not find it optimal to charge a wage below $w_{A}^{A}$, whenever it wants the firm to settle in country $A$. Total production of good $x$ is then $X_{A}=x_{a}^{A}+x_{c}^{A}$ [see eq. (4)]. Substituting into (8), the union's wage surplus when it sets the wage according to $(7)$ is

$$
\Omega_{A}^{A}=\frac{2}{3 \beta}[\sqrt{n}(\alpha-\bar{w})-\delta] \delta,
$$

where

$$
\delta \equiv \sqrt{9 \beta\left(t_{A}-t_{B}\right)+(1-n)(\alpha-\bar{w})^{2}} .
$$

The union in country $A$ compares the wage surplus in the case where it is able to attract the outside firm, and in the case where it chooses instead the 'outside option' of letting the firm go to country $B$ and extracting a high wage from the domestic monopolist. Hence the union compares $\Omega_{A}^{A}$ in (11) with $\Omega_{A}^{B}$ in (10). Since the term $\delta$ includes the tax differential $t_{A}-t_{B}$, the union's decision of whether to attract the outside firm will be affected by the tax rates that governments choose in the first stage. Setting $\Omega_{A}^{A}=\Omega_{A}^{B}$ yields the maximum tax differential that will still induce the union to set the wage $w_{A}^{A}$ and hence attract the outside firm in equilibrium. This higher critical value for the tax differential (superscript $H$ ) is ${ }^{13}$

$$
\left(t_{A}-t_{B}\right)^{H}=\frac{(25 n-16)(\alpha-\bar{w})^{2}}{144 \beta} .
$$

\footnotetext{
${ }^{13}$ Equation (11) is quadratic in the tax differential so that there are two solutions for $\left(t_{A}-t_{B}\right)$ that solve $\Omega_{A}^{A}=\Omega_{A}^{B}$. Since we are searching for the highest possible tax differential that is compatible with an equilibrium in Regime $A$, only the larger of these two solutions is relevant.
} 
As long as $t_{A}-t_{B}$ is less than this critical value, the union will be better off (or at least as well off) with the outside firm and hence the location equilibrium will be in Regime $A$. Once $t_{A}-t_{B}$ surpasses the critical threshold in (13), the union will no longer try to attract the outside firm and will instead set $w_{A}^{B}$ according to (9). In this case the location equilibrium will thus be in Regime $B$.

At this stage we cannot exclude the possibility that the union will find it optimal to charge a wage below the maximum wage that is compatible with a location equilibrium in Regime $A$. In other words we also have to consider the case where the constraint $w_{A}<w_{A}^{A}$ is not binding. In this case the union's optimising behaviour in Regime $A$ gives

$$
\frac{\partial \Omega_{A}^{A}}{\partial w_{A}}=\frac{2 n\left(\alpha+\bar{w}-2 w_{A}\right)}{\beta}=0 \quad \Leftrightarrow \quad \tilde{w}_{A}^{A}=\frac{\alpha+\bar{w}}{2}
$$

where $\tilde{w}_{A}^{A}$ denotes the union's unconstrained wage optimum in Regime $A$. This wage rate corresponds to the union's optimal wage in Regime $B$ [eq. (9)]. We can thus derive a lower threshold (superscript $L$ ) for the tax differential, which is defined by the equality of $w_{A}^{A}$ in (7) and $\tilde{w}_{A}^{A}$ in (14). This is

$$
\left(t_{A}-t_{B}\right)^{L}=\frac{(20 n-16)(\alpha-\bar{w})^{2}}{144 \beta} .
$$

Since $w_{A}^{A}$ is falling in $\left(t_{A}-t_{B}\right)$ whereas $\tilde{w}_{A}^{A}$ is independent of taxes, any tax differential below this critical value implies that $\tilde{w}_{A}^{A}<w_{A}^{A}$. In this case the tax rate in country $A$ is so low, relative to that of country $B$, that the union is not constrained by the condition to attract the outside firm. It optimally chooses $\tilde{w}_{A}^{A}$ according to (14) and since this wage is below $w_{A}^{A}$, the outside firm will surely locate in country $A$. We label this case Regime $A 2$. In contrast, we denote by Regime $A 1$ the case where the union's wage policy is determined by (7) and hence the condition to attract the outside firm is binding. We can then characterise the equilibrium wage policy of country $A$ 's union in each of the three regimes $B, A 1$ and $A 2$, as a function of the tax differential decided by governments in the first stage. Starting with high values of $\left(t_{A}-t_{B}\right)$ gives:

$$
\begin{array}{llll}
(R B): & w_{A}=w_{A}^{B}=(\alpha+\bar{w}) / 2 & \text { if } & \left(t_{A}-t_{B}\right)>\left(t_{A}-t_{B}\right)^{H} ; \\
(R A 1): & w_{A}=w_{A}^{A}=\alpha-(\delta \sqrt{n} / n) & \text { if } & \left(t_{A}-t_{B}\right)^{L} \leq\left(t_{A}-t_{B}\right) \leq\left(t_{A}-t_{B}\right)^{H} ; \\
(R A 2): & w_{A}=\tilde{w}_{A}^{A}=(\alpha+\bar{w}) / 2 & \text { if } & \left(t_{A}-t_{B}\right)<\left(t_{A}-t_{B}\right)^{L} ;
\end{array}
$$

where $\delta$ is given in (12) and $\left(t_{A}-t_{B}\right)^{H}$ and $\left(t_{A}-t_{B}\right)^{L}$ are given in (13) and (15). 


\section{Stage one: The governments}

In the first stage of the game, the two governments choose a lump-sum tax or subsidy on the entry of the outside firm. We assume that each government maximises the sum of utilities of the worker-consumers in its jurisdiction. The optimal policy for each country is derived by comparing the welfare levels in the case where the country hosts the firm and in the case where it does not. National welfare in each country is obtained from the individual utility functions (1), where the per-capita budget constraints (2) are used to substitute out for $z_{i} \cdot{ }^{14}$ Employing the first-order condition of the consumers' optimisation problem and aggregating over households in the two countries gives the following national welfare measures:

$$
\begin{gathered}
U_{A}=n u_{A}=\left(\alpha-p_{A}\right) \frac{X_{A}}{2}+\Omega_{A}+n \bar{w}+\pi_{a}+t_{A} ; \\
U_{B}=(1-n) u_{B}=\left(\alpha-p_{B}\right) \frac{X_{B}}{2}+(1-n) \bar{w}+\pi_{b}+t_{B} .
\end{gathered}
$$

It is then straightforward to show that if country $A$ attracts the outside firm, the equilibrium must be in Regime $A 1$ and it lies at the borderline to Regime $B$.

Proposition 1 In any equilibrium where country $A$ attracts the firm, the tax differential is given by $\left(t_{A}-t_{B}\right)^{H}$ in (13) and the union sets the wage according to $w_{A}^{A}$ in (7).

Proof: See Appendix 1.

The intuition for this result is as follows. First, it is straightforward to see that the equilibrium can never be in Regime $A 2$. In this regime the wage rate is given by $\tilde{w}_{A}^{A}$ in (14), which in turn is below $w_{A}^{A}$ in (7). Setting the wage below $w_{A}^{A}$ implies, however, that the union leaves a location rent to the outside firm, in excess of what is needed to attract it to country $A$. This is anticipated by country $A$ 's government, which raises $t_{A}$ and thus brings down $w_{A}^{A}$ until $\tilde{w}_{A}^{A}=w_{A}^{A}$. This tax increase will not raise the level of the equilibrium wage and its only effect is to increase country $A$ 's tax revenue at the expense of firm c's profits. This clearly must be beneficial for country $A$. The

\footnotetext{
${ }^{14}$ Note that in country $A$ the per-capita budget constraints, and hence the per-capita utility levels $u_{A}$, must be interpreted as weighted averages of the incomes and utilities of unionised and nonunionised workers.
} 
second part of the proof shows that optimal tax policy in country $A$ always implies an equilibrium at the boundary of Regimes $A 1$ and $B$, rather than in the interior of Regime $A 1$. Intuitively, $w_{A}^{A}$ is the union's optimal wage policy in Regime $A 1$, which is a falling function of $\left(t_{A}-t_{B}\right)$. Therefore a tax rise in country $A$ reduces the wage rate and hence the distortion in sector $x$, as the entry tax for the outside firm does not distort output decisions at the margin. In sum, therefore, the government of country $A$ will fully exploit its taxing power vis-à-vis both the domestic union and the foreign firm. In any equilibrium in Regime $A$ the union in country $A$ will thus receive no rent over and above the wage surplus that it obtains in Regime $B$, and the outside firm will only obtain the net profits that it could also earn in country $B$.

We can exploit the implication of Proposition 1 that the union's wage surplus is equal in Regimes $A$ and $B$ to get $\Omega_{A}^{A}=\Omega_{A}^{B}=n(\alpha-\bar{w})^{2} /(8 \beta)$. Substituting this along with (3) and $p_{A}^{A}$ and $\pi_{a}^{A}$ from (5) and (6) into (17a) yields country $A$ 's welfare in Regime $A$ as a function of the two tax rates:

$$
U_{A}^{A}=4 t_{A}-3 t_{B}+\frac{(8-5 n)(\alpha-\bar{w})^{2}}{24 \beta}+n \bar{w} .
$$

In Regime $B$, welfare in country $A$ is instead derived using $p_{A}^{B}$ and $\pi_{a}^{B}$ from (5) and (6) along with (10) and $t_{A}=0$ in (17a). This gives

$$
U_{A}^{B}=\frac{7 n(\alpha-\bar{w})^{2}}{32 \beta}+n \bar{w} .
$$

Setting $U_{A}^{A}=U_{A}^{B}$ and noting that $U_{A}^{A}$ is a rising function of $t_{A}$ gives the best offer (denoted by a superscript $o$ ) that country $A$ 's government is willing to make to the outside firm $c$. This is the minimum tax that country $A$ is willing to accept, or the maximum subsidy that it is willing to pay, in order to host this firm:

$$
t_{A}^{o}=\frac{1}{4}\left[3 t_{B}+\frac{(\alpha-\bar{w})^{2}}{96 \beta}(41 n-32)\right] .
$$

Country $A$ 's best offer $t_{A}^{o}$ can be positive or negative. It is a rising function of $t_{B}$ since a higher entry tax in country $B$ raises the wage rate that country $A$ 's union charges in a Regime $A$ equilibrium [see eq. (7)]. The resulting efficiency losses must be compensated by a higher lump-sum tax (or a lower subsidy), in order to make Regime $A$ at least as attractive as Regime $B$ from the perspective of $A$ 's government. 
In a similar way we can compute the best tax offer that country $B$ is willing to make to the firm. In Regime $A$, where country $B$ 's tax collections are zero, we substitute $p_{B}^{A}$ and $\pi_{b}^{A}$ from (5) and (6) along with $t_{B}=0$ into (17b). This yields

$$
U_{B}^{A}=(1-n)\left[\frac{3(\alpha-\bar{w})^{2}}{8 \beta}+\bar{w}\right]
$$

Alternatively, if country $B$ attracts the firm, we use $p_{B}^{B}$ and $\pi_{b}^{B}$ from (5) and (6) in (17b). In Regime $B$, national welfare in country $B$ will then amount to

$$
U_{B}^{B}=t_{B}+(1-n)\left[\frac{(\alpha-\bar{w})^{2}}{3 \beta}+\bar{w}\right] .
$$

Setting $U_{B}^{A}=U_{B}^{B}$ gives country $B$ 's best offer:

$$
t_{B}^{o}=\frac{(1-n)(\alpha-\bar{w})^{2}}{24 \beta} .
$$

Country B's best offer is strictly positive, i.e., it is only willing to host the firm if it receives a positive entry fee. The reason is that the entry of the foreign firm will simultaneously reduce the profits by country $B$ 's incumbent firm and lead to an efficiency gain as the market becomes less concentrated. In equilibrium the fall in domestic profits is the dominant effect, thus requiring positive tax receipts to compensate country $B$ 's residents for the fall in their profit incomes. Note also that $t_{B}^{o}$ is independent of $t_{A}$. This is because the interdependence of tax rates arises only through their effect on wage policies in our model (see the discussion of $t_{A}^{o}$ above) and the wage rate of country $B$ is fixed.

The equilibrium in the bidding game is derived as follows. The two countries continuously reduce their tax rates until the first country has reached its best offer and is therefore not willing to reduce its tax rate any further. The other country will make an offer that is marginally more attractive to the outside firm and attract the FDI.

Let us first consider under which conditions country $A$ will attract the firm in equilibrium. Using Proposition 1, we can derive country $A$ 's optimal tax policy by substituting country $B$ 's best offer (21) into the equilibrium tax differential $\left(t_{A}-t_{B}\right)^{H}$ in (13). This gives the maximum (and hence optimal) tax rate that country $A$ can charge if it wants to attract the firm:

$$
t_{A}^{*}=\frac{(19 n-10)(\alpha-\bar{w})^{2}}{144 \beta}
$$


Note that the optimal tax rate charged by country $A$ is not necessarily positive and in fact will be negative when countries are of equal size $(n=0.5)$. This reflects the fact that country $A$ is constrained in its tax policy by the presence of a domestic union. Any lump-sum tax on the firm in excess of $t_{A}^{*}$ will cause the union to set a wage rate that makes it unattractive for the foreign firm to enter market $A$.

Substituting country $A$ 's optimal tax rate $\left(t_{A}^{*}\right)$ and country $B$ 's best offer $\left(t_{B}^{o}\right)$ into (18a) yields country $A$ 's maximised welfare in Regime $A$ :

$$
U_{A}^{A *}=\frac{(32 n-5)(\alpha-\bar{w})^{2}}{72 \beta}+n \bar{w} .
$$

The final step is to compare this expression with the alternative utility level that country $A$ would achieve in Regime $B$. This shows that country $A$ is better off with the outside firm if and only if its market size exceeds a critical threshold: ${ }^{15}$

$$
U_{A}^{A *}>U_{A}^{B} \Longleftrightarrow n>n^{c}=4 / 13
$$

Equation (24) shows that there is a range of parameter values where the unionised country also has the smaller market, yet still attracts the outside firm in equilibrium. It can further be verified that the outside firm indeed makes positive net profits when locating in country $A .^{16}$

In the opposite case where country $B$ hosts the firm, the equilibrium is characterised by country $A$ making its best offer in (19) while country $B$ charges the highest possible level of $t_{B}$ that still attracts the firm to this country. This implies that country $B$ sets its tax rate such that country $A$ 's best offer in (19) is marginally higher than the maximum tax differential that country $A$ can afford to attract the firm [eq. (13)]. Solving for the level of $t_{B}$ that equates $t_{A}$ in (19) and in (13) gives

$$
t_{B}^{*}=\frac{(\alpha-\bar{w})^{2}}{288 \beta}(32-77 n) .
$$

\footnotetext{
${ }^{15}$ It is easily verified that the same result can be obtained from the condition that country $A$ 's optimal tax rate $t_{A}^{*}$ in (22) must be at least as high as its best offer $t_{A}^{o}$ in (19), where the latter is evaluated at $t_{B}^{o}$ in $(21)$.

${ }^{16}$ From the gross profit expression for $\pi_{c}^{A}$ in (6), the wage equation (16) and the two tax rates (21) and (22), we get net profits of $\pi_{c}^{A}-t_{A}^{*}=5(1-n)(\alpha-w)^{2} /(72 \beta)$ which is unambiguously positive. By construction, this is the same level of net profits that the outside firm could earn in country $B$.
} 
Country $B$ will attract the outside firm if it marginally underbids this level of tax. Substituting in (20b) yields country $B$ 's maximised welfare in Regime $B$

$$
U_{B}^{B *}=\frac{(\alpha-\bar{w})^{2}}{288 \beta}(128-173 n)+(1-n) \bar{w} .
$$

To see whether country $B$ will benefit from hosting the firm, we compare (26) with (20a), or alternatively $t_{B}^{*}$ in (25) with $t_{B}^{o}$ in (21). Consistent with the above result, either method shows that country $B$ is willing to host the firm when $n<n^{c}=4 / 13$.

Taken together, these results determine the equilibrium location of the outside firm and the equilibrium tax rate imposed by the host country for each of the different values of the country size parameter $n$. For $n \geq 4 / 13$ country $A$ will host the firm and the equilibrium tax rate is given by (22). In contrast, when $n<4 / 13$ country $B$ hosts the firm and the equilibrium tax rate is given by (25). We summarise our results in

Proposition 2 In the tax/subsidy game between two countries that differ with respect to union power and size, there is a critical market size parameter $n^{c}=4 / 13$ such that for all $n \geq n^{c}$ the unionised country (country $A$ ) attracts the outside firm in equilibrium, whereas for $n<4 / 13$ the non-unionised country (country B) hosts the firm.

The result in Proposition 2 is surprising at first glance as the unionised country seems to be at a disadvantage in the location competition for the outside firm. In the absence of a union, it is always the larger country which wins the competition for an outside firm (Haufler and Wooton, 1999; Bjorvatn and Eckel, 2006). ${ }^{17}$ First intuition would thus suggest that the unionised country $A$ needs to have a larger market than country $B$ in order to attract the FDI. Proposition 2 shows, however, that exactly the opposite is true and having a union can indeed offset a (limited) size disadvantage that country $A$ has vis-à-vis country $B$. The reasoning underlying this result is that country $A$ has a stronger incentive to attract the outside firm, as this will help in moderating the wage claims of the domestic union. In country $B$ only the product market distortion

\footnotetext{
${ }^{17}$ This result can also be demonstrated in our framework when the wage rate in country $A$ is set at the competitive level $\bar{w}$. In this case the highest tax rate that each country can charge and still attract the outside firm $c$ are $t_{A}^{*}=\left(\pi_{c}^{A}-\pi_{c}^{B}\right)-\left(U_{B}^{B}-U_{B}^{A}\right)$, which equals $\left[(13 n-5)(\alpha-\bar{w})^{2}\right] /(72 \beta)$; and $t_{B}^{*}=\left(\pi_{c}^{B}-\pi_{c}^{A}\right)-\left(U_{A}^{A}-U_{A}^{B}\right)=\left[(8-13 n)(\alpha-\bar{w})^{2}\right] /(72 \beta)$. This shows that country $A$ can afford the higher tax, and will attract the investment in equilibrium, whenever $n>0.5$.
} 
is ameliorated when the foreign firm $c$ enters the market. In country $A$, however, the efficiency gain is further raised by the fact that the unionised wage will fall when the foreign firm enters the market. Substituting (21) and (22) in (16) shows that the equilibrium wage in Regime $A$ is

$$
w_{A}^{A *}=\frac{(\alpha+3 \bar{w})}{4}=\bar{w}+\frac{(\alpha-\bar{w})}{4} .
$$

The equilibrium wage in Regime $A$ is above the competitive level, but it is unambiguously lower than the wage rate that the union would set in Regime $B$ [see eq. (16)]. This additional benefit of hosting the outside firm is reflected in the bid of country $A$ 's government.

The greater likelihood to attract the outside firm does not imply, however, that coun$\operatorname{try} A$ also has the higher per-capita welfare in equilibrium. Instead we get the stark result that per-capita welfare is always lower in country $A$, in either of the two possible regimes and for any distribution of population size. This is summarised in

Proposition 3 In either Regime $A$ or Regime $B$, and for any level of $n<1$, percapita welfare in the unionised country (country A) is less than per-capita welfare in the non-unionised country (country $B$ ).

Proof: In Regime $A$, dividing $U_{A}^{A *}$ in (23) by $n$ and $U_{B}^{A}$ in (20a) by $(1-n)$ shows that $U_{A}^{A *} / n<U_{B}^{A} /(1-n) \forall n \geq 4 / 13$, where $n \geq 4 / 13$ holds in Regime $A$ from Proposition 2. In Regime $B$ we divide $U_{A}^{B}$ in (18b) by $n$ and $U_{B}^{B *}$ in (26) by $(1-n)$. This gives $U_{A}^{B} / n<U_{B}^{B *} /(1-n) \forall n<4 / 13$, where $n<4 / 13$ holds in Regime $B$.

A simple way to explain this result is to compare the different ways in which countries $A$ and $B$ can (partly) extract the profits from the outside firm, if it locates in their jurisdiction. In country $B$ only the tax instrument is available for this purpose, but this instrument causes no allocative distortions. In country $A$, in contrast, profit extraction occurs through a mix of higher wages and lump-sum taxes. Since the wage instrument is distortive but must nevertheless be used in order to ensure the compliance of the union, country $A$ 's set of instruments to capture the outside firm's profits is less efficient, on average. Since the overall level of profit extraction is fixed for both countries by the arbitrage condition that governs firm c's location choice, these efficiency losses translate into a lower per-capita welfare level in country $A$. 
Figure 1: Per-capita welfare as a function of population size

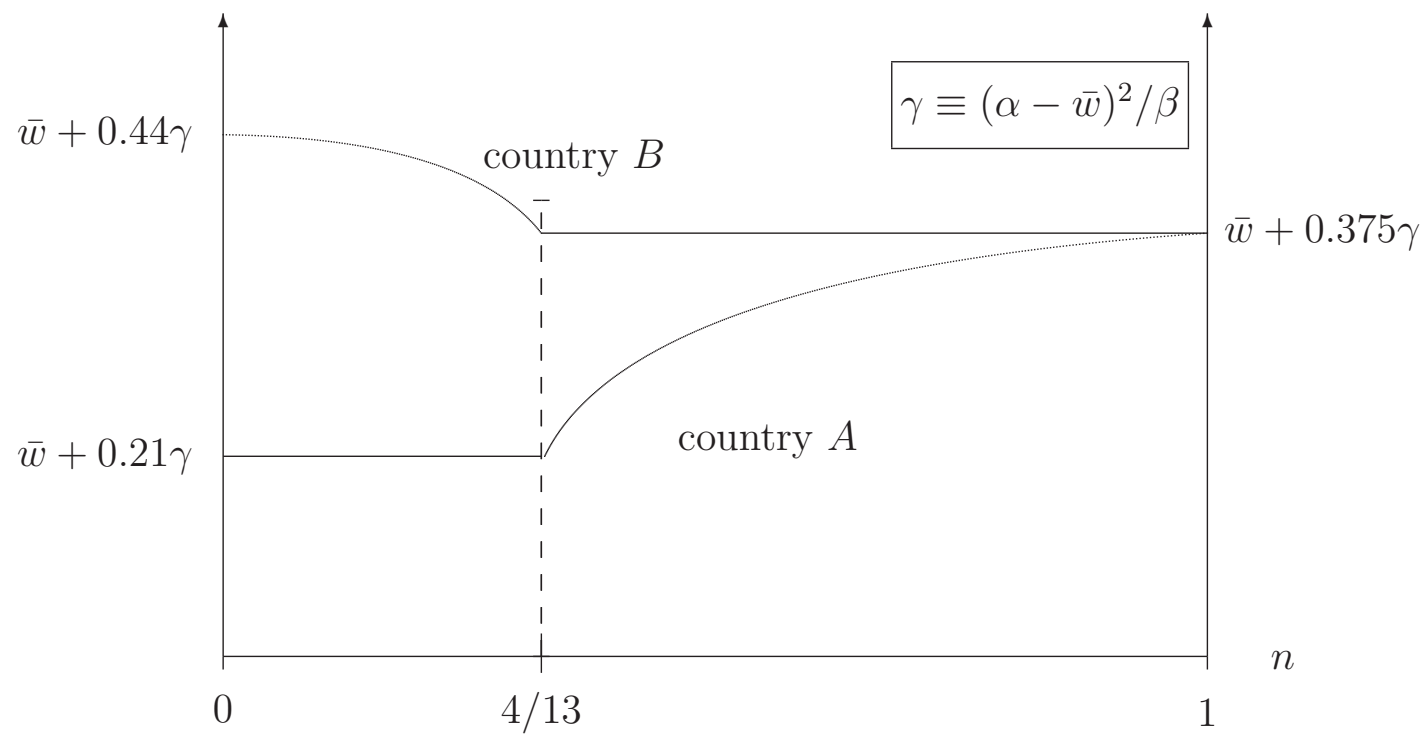

Figure 1 summarises the per-capita welfare levels in both countries for different distributions of population size. The graph shows that for each country per-capita welfare is higher when this country attracts the outside firm, and within this regime the host country's welfare is rising in the local population size. This is because the location of the outside firm generates additional rents and the host country is able to capture an increasing share of these rents when its market size advantage vis-à-vis the competing region grows. Finally Figure 1 shows that per-capita welfare in country $B$ is above that of country $A$ for all interior distributions of population size $0<n<1$.

Lastly, we show that even though unionisation leads to the average per-capita welfare in country $A$ being below that in country $B$, the unionised workers in country $A$ are better off than they would be in the absence of the union. This result holds under the condition that the share of workers in the $x$ sector does not exceed a critical threshold.

Proposition 4 If the share of workers in the unionised sector is below a critical value $s_{A}^{c}=4 / 9$, the per-capita welfare of unionised workers in country $A$ is higher than in the absence of the union. This holds true in both regimes and for all $n<1$.

Proof: See Appendix 2. 
Proposition 4 shows that the union creates winners and losers in country $A$, but the gains to unionised workers are lower than the losses to the non-unionised workers in the numéraire sector (see Proposition 3). The upper limit on the size of the unionised sector ensures that the efficiency losses caused by the union will not be so large as to thwart the redistributive gains to workers in sector $x$. We have already assumed above, in deriving the objective function of the union [eq. (8)], that the share of workers in the $x$ industry is small. With this constraint unionisation is thus indeed beneficial for those workers in country $A$ that receive the higher union wage.

\section{Robustness of results}

In this section we examine the robustness of our results when some of the model assumptions are changed. In Appendix 3 we analyse the case where trade in good $x$ takes place, but per-unit transport costs $\tau$ are incurred when shipping goods between countries $A$ and $B$. The basic mechanisms of this extended model are completely analogous to our analysis in the previous sections. All calculations are considerably more tedious, however, due to the dependence of prices and quantities on the trade cost parameter and on wages in both countries. To limit the complexity of the resulting expressions we confine the analysis in Appendix 3 to the case where countries are of equal size $(n=0.5) .{ }^{18}$ For this case we show that the unionised country will attract the firm in equilibrium. By continuity, this result will continue to hold for small differences in country size. Hence the qualitative result in Proposition 2 carries over to an extended model with trade between countries $A$ and $B$. Moreover, it is also shown in Appendix 3 that, for $n=0.5$, the unionised country has lower per-capita welfare than the non-unionised country. Hence Proposition 3 also carries over to a model with costly trade, at least when countries are of similar size.

A second issue is whether and how the results of our model are affected when the sequence of play is altered. ${ }^{19}$ One alternative scenario is that the union's decisions are

\footnotetext{
${ }^{18} \mathrm{~A}$ further simplifying assumption made in Appendix 3 is that exogenous trade costs are low enough so that the union cannot shut down trade by choosing sufficiently high wages. This last possibility is explicitly analysed in Lommerud et al. (2003).

${ }^{19}$ The set of results for these alternative time structures is available from the authors upon request.
} 
of a longer-term nature than tax policies and hence the union in country $A$ chooses the wage rate before the two governments set taxes. The result that the unionised country can attract the firm, even if it has the smaller market, carries over to this alternative setting. In fact, the critical size parameter $n^{c}$, at which the switch between Regimes $A$ and $B$ occurs, is exactly the same as in our benchmark analysis. This can be explained as follows. When the union has the first-mover advantage it is able to appropriate the rents that arise from the location of the outside firm. Hence the union will voluntarily moderate wages in order to attract the firm, if this increases its wage surplus. At the critical level of country size $n^{c}$ no rents arise for any player so that the different order of moves has no further consequences. For $n>n^{c}$ the changed sequence does matter, however, as the union can now charge the maximum wage at which country $A$ 's government is still willing to set the tax sufficiently low to attract the firm. In comparison to our benchmark case, this will lead to higher wages and thus a lower average utility in country $A$.

Let us now consider a scenario where the outside firm has already settled in one of the countries before country $A$ 's union chooses the local wage rate. This implies that FDI can be attracted by lump-sum location subsidies, but once the investment has been made it is locked in the country and only the output level can be adjusted to a rise in wage costs. Tax rates are thus determined in the first stage, the outside firm's location choice is made in the second stage and the wage in country $A$ is set in the third stage. In the fourth and final stage the three firms choose output levels, given that the location of all firms has already been fixed. In this case the union will set the same monopoly wage in Regimes $A$ and $B$, as the outside firm is immobile at the time when the wage rate in country $A$ is chosen. Hence tax policy is unable in this case to induce wage moderation. As a result, country $A$ 's government is no longer willing to offer the firm a subsidy that fully compensates the firm for the higher wage in country $A$ and the critical market size at which the unionised country attracts the firm in equilibrium rises above $n=0.5$. Moreover, average welfare in country $A$ is lower in this case than in any of the other scenarios. The general lesson from these alternative sequences of play is that wage moderation can still be expected when unions move prior to governments, but it is crucial that mobile firms can react with their location decisions to the wage rate they face in the unionised country. As we have discussed above, however, multinational 
firms have increased opportunities to relocate production across countries and many examples show that they also use this opportunity. Hence unions do in fact have to take this constraint into account.

As a final note, we have chosen the most straightforward way to model asymmetric union power by assuming that a union is present in country $A$ whereas the labour market in country $B$ is competitive. We expect our results to carry over qualitatively to the case where a union is also present in country $B$, but it is less powerful than that of country $A$. If union power is fully symmetric in countries $A$ and $B$ the model will again lead to the well-known result that the larger country attracts the investment, other things being equal.

\section{Conclusion}

In this paper we have analysed a model of tax competition between two countries that differ with respect to both market size and the degree of unionisation. This model leads to the seemingly counterintuitive result that market power in the labour market raises the likelihood that the unionised country attracts an internationally mobile firm. More precisely, the unionised country can win the foreign direct investment in equilibrium even if it offers the smaller market, as long as the disadvantage in market size is not too large. The core reason underlying this result is that the government of the unionised country will provide a generous tax environment to the firm as a means to induce wage moderation from its domestic union. Foreign direct investment plays a crucial role in this process because it offers a discrete increase in employment opportunities when the union 'cooperates' in attracting the mobile firm. We have also argued that the basic result holds regardless of whether trade occurs between the competing countries or not, and whether tax policies or wage policies are set first.

Our analysis may help explain why high investment subsidies are commonplace in locations with high wages and union power. It also offers the testable hypothesis that a higher degree of union power will lead to more generous tax and subsidy policies towards foreign direct investment. For the United States, there is indeed some empirical support for the proposition that a higher degree of unionisation leads to more foreign direct investment, other things being equal (see Coughlin et al., 1991). A more direct test 
of our central result would be to regress the equilibrium levels of taxes and subsidies, rather than the level of foreign direct investment, on a suitable indicator of union power.

Our model can be extended in several directions. One possible route is to widen the set of policy instruments in the hands of governments and to include distortionary taxes. We would expect that the overall policy package in the unionised country would still be more generous towards foreign direct investment than the incentives granted by a country with (more) competitive labour markets. Hence the unionised country will again attract more FDI, other things being equal. However, when only distortionary taxes can be used to capture the outside firm's profits, then it is no longer clear that profit extraction by means of higher wages is inferior from an efficiency perspective. Hence in such a model the unionised country will not necessarily have a lower percapita welfare in equilibrium. A second possible extension is to relax the assumption of a monopoly union and replace it by a bargaining game between the union and the firm(s). Giving the incumbent firm in the unionised country the power to bargain over wages will add a further strategic dimension to the model, as the incumbent may accept higher wages in order to keep foreign competitors out of its home market. This is an issue that we want to address in future research. 


\section{Appendix}

\section{Appendix 1: Proof of Proposition 1}

To derive country $A$ 's welfare in Regime $A$ we first calculate $X_{A}=x_{a}^{A}+x_{c}^{A}=2 n(\alpha-$ $\left.w_{A}\right) /(3 \beta)$ from (4). Using this in the wage surplus definition (8) and substituting the resulting expression along with $p_{A}^{A}$ and $\pi_{a}^{A}$ from (5) and (6) into (17a) yields

$$
U_{A}^{A}=\frac{n}{3 \beta}\left(\alpha-w_{A}\right)\left(\alpha+w_{A}-2 \bar{w}\right)+n \bar{w}+t_{A} .
$$

In Regime $A 2$, substitute $\tilde{w}_{A}^{A}$ from (16) into (A.1). This yields

$$
U_{A}^{A 2}=\frac{n}{4}(\alpha-\bar{w})^{2}+n \bar{w}+t_{A}
$$

Hence $\partial U_{A}^{A 2} / \partial t_{A}=1$ throughout Regime $A 2$, implying that it is optimal for country $A$ 's government to raise taxes until Regime $A 1$ is reached.

In Regime $A 1$, substitute $w_{A}^{A}$ from (16) into (A.1). This yields

$$
U_{A}^{A 1}=\frac{\delta}{3 \beta}\left[2 \sqrt{n}(\alpha-\bar{w}-\delta]+n \bar{w}+t_{A} .\right.
$$

Differentiating with respect to $t_{A}$ gives

$$
\frac{\partial U_{A}^{A 1}}{\partial t_{A}}=\frac{2}{3 \beta}\left[\sqrt{n}(\alpha-\bar{w}-\delta] \frac{\partial \delta}{\partial t_{A}}+1>0\right.
$$

since the term in the squared bracket equals $\Omega_{A}^{A} / \delta>0$ and $\partial \delta / \partial t_{A}>0$ from (11). Hence, in Regime $A 1$, country $A$ 's government will raise taxes until the borderline to Regime $B$ is reached. This implies that country $A$ sets its tax according to (13).

\section{Appendix 2: Proof of Proposition 4}

To compare the unionised workers' welfare in the presence and in the absence of a trade union, three cases have to be distinguished: $(i)$ if $0<n<4 / 13$ the equilibrium is in Regime $B$ with and without a union in country $A$; (ii) if $4 / 13 \leq n \leq 0.5$ the equilibrium is in Regime $A$ in the presence of a union, but in Regime $B$ if there is no union in country $A$; ( iii) if $0.5<n$ the equilibrium is always in Regime $A$. (cf. footnote 17). 
In case $(i)$ the average per-capita welfare level in country $A, U_{A}^{B} / n$ [eq. (18b)], must be decomposed into the utility of unionised and that of non-unionised workers. Since the wage surplus of a unionised worker is $(\alpha-\bar{w}) / 2$ in Regime $B$ [eq. (9)] the per-capita welfare of this group in country $A$ is

$$
u_{A}^{u n i o n}=\frac{(\alpha-\bar{w})}{2}\left[\frac{7(\alpha-\bar{w})}{16 \beta}+\left(1-s_{A}\right)\right]+\bar{w} .
$$

Alternatively, in the absence of a union the per-capita welfare level in country $A$ would be the same as that of country $B$ 's workers in Regime $A$, which equals $U_{B}^{A} /(1-n)$ in eq. (20a). Hence in case $(i)$ the per-capita welfare differential for unionised workers in country $A$ is

$$
\Delta u_{A}^{i}=\frac{(\alpha-\bar{w})}{2}\left[\frac{7(\alpha-\bar{w})}{16 \beta}+\left(1-s_{A}\right)-\frac{3(\alpha-\bar{w})}{4 \beta}\right]
$$

which is falling in $s_{A}$. Setting this difference equal to zero yields an upper limit for the share of workers in sector $x$ equal to $s_{A}^{i}=1-[5(\alpha-\bar{w}) /(16 \beta)]$. Moreover, in a Regime $B$ equilibrium it must hold that $s_{A}^{i}=x_{a}^{B} / n=(\alpha-\bar{w}) /(4 \beta)$, where the first equality holds because one worker is needed to produce one unit of good $x$ and the second equality follows from substituting (9) in (4). Combining the two equations gives the case-specific critical value $s_{A}^{i}=4 / 9$.

In case $(i i)$, the per-capita welfare level of a unionised worker in country $A$ is derived from the average per-capita utility $U_{A}^{A *} / n$ in (23), and the wage surplus in Regime $A$, which is $(\alpha-\bar{w}) / 4$ [eq. (27)]. Alternatively, in the absence of a union the per-capita welfare level in country $A$ is again given by $U_{B}^{A} /(1-n)$ in eq. (20a). This yields a per-capita welfare difference for unionised workers in this case equal to

$$
\Delta u_{A}^{i i}=\frac{(\alpha-\bar{w})}{4}\left[\frac{(32 n-5)(\alpha-\bar{w})}{18 \beta n}+\left(1-s_{A}\right)-\frac{3(\alpha-\bar{w})}{2 \beta}\right] .
$$

This welfare difference is rising in $n$ so that the case-specific minimum occurs at $n=$ 4/13. Substituting this value and equalising the two utilities yields a critical upper bound for $s_{A}$ equal to $s_{A}^{i i}=1-[5(\alpha-\bar{w}) /(8 \beta)]$. Moreover, in a Regime $A$ equilibrium it must hold that $s_{A}=\left(x_{a}^{A}+x_{c}^{A}\right) / n=(\alpha-\bar{w}) /(2 \beta)$, where we use (27) and (4). Combining the two equations gives $s_{A}^{i i}=4 / 9$ as the strictest case-specific condition.

Finally, in case ( $i i i$ ) the per-capita welfare of a unionised worker from having the union is again derived from (23) and (27). The level in the absence of the union is obtained 
by using (20b), duly replacing $(1-n)$ by $n$ and replacing $t_{B}$ by $t_{A}^{*}$, where $t_{A}^{*}$ is given in footnote 17 . This yields a per-capita welfare difference for unionised workers of

$$
\Delta u_{A}^{i i i}=\frac{(\alpha-\bar{w})}{4}\left[\frac{(32 n-5)(\alpha-\bar{w})}{18 \beta n}+\left(1-s_{A}\right)-\frac{(37 n-5)(\alpha-w)}{18 \beta n}\right] .
$$

Setting this difference equal to zero yields $s_{A}^{i i i}=1-[5(\alpha-\bar{w}) /(18 \beta)]$. Since $s_{A}=$ $\left(x_{a}^{A}+x_{c}^{A}\right) / n=(\alpha-\bar{w}) /(2 \beta)$ holds again in this case, the critical value is $s_{A}^{i i i}=9 / 14$. The upper bound on the share of unionised workers which ensures that each worker benefits from the union, irrespective of the level of $n$, is thus $s_{A}^{c}=\min \left\{s_{A}^{i}, s_{A}^{i i}, s_{A}^{i i i}\right\}=4 / 9$.

\section{Appendix 3: The model with trade}

We adopt the segmented market hypothesis in the framework of a 'reciprocal dumping' model à la Brander and Krugman (1983). For expositional ease, we assume countries to be of equal size, i.e. $n=0.5$. We assume that trade costs are below the prohibitive level so that two-way trade always takes place. The game in the last stage is changed in that there are now three active firms in both markets. With per unit trade costs of $\tau$, solving the third stage of the game yields firm- and regime-specific profits of

$$
\begin{aligned}
& \pi_{a}^{A}=\pi_{c}^{A}=\frac{\left(\alpha-2 w_{A}^{A}+\bar{w}-2 \tau\right)^{2}}{32 \beta}+\frac{\left(\alpha-2 w_{A}^{A}+\bar{w}+\tau\right)^{2}}{32 \beta} ; \\
& \pi_{b}^{A}=\frac{\left(\alpha+2 w_{A}^{A}-3 \bar{w}-3 \tau\right)^{2}}{32 \beta}+\frac{\left(\alpha+2 w_{A}^{A}-3 \bar{w}+2 \tau\right)^{2}}{32 \beta} ; \\
& \pi_{a}^{B}=\frac{\left(\alpha-3 w_{A}^{B}+2 \bar{w}-3 \tau\right)^{2}}{32 \beta}+\frac{\left(\alpha-3 w_{A}^{B}+2 \bar{w}+2 \tau\right)^{2}}{32 \beta} ; \\
& \pi_{b}^{B}=\pi_{c}^{B}=\frac{\left(\alpha+w_{A}^{B}-2 \bar{w}-2 \tau\right)^{2}}{32 \beta}+\frac{\left(\alpha+w_{A}^{B}-2 \bar{w}+\tau\right)^{2}}{32 \beta} .
\end{aligned}
$$

The first terms in these expressions refer to profits in market $A$, whereas the second terms give the profits in market $B$. By analogy to the benchmark model without trade we can infer a wage rate in country $A$ for which the outside firm $c$ is just indifferent between the two locations. This wage rate, which depends on the exogenous trade cost parameter, taxes, and also on country $A$ 's wage rate in Regime $B$ is:

$$
w_{A}^{A}=\frac{1}{4}\left[2 \alpha+2 \bar{w}-\tau-\sqrt{\left(2 \alpha-4 \bar{w}-\tau+2 w_{A}^{B}\right)^{2}+64 \beta\left(t_{A}-t_{B}\right)}\right] .
$$

Employing our analysis in the main part of the paper (cf. Proposition 1) we assume that the union will find it optimal to set the wage just at this level, if it wants to 
attract the firm. The union's alternative is to forgo the outside firm and impose the surplus-maximising wage on the domestic monopolist. The latter is given by

$$
w_{A}^{B}=\frac{1}{12}(2 \alpha+10 \bar{w}-\tau)
$$

This wage rate can be substituted into (A.2). Defining the union surplus as in (8), equating the regime-specific expressions in Regimes $A$ and $B\left(\Omega_{A}^{A}=\Omega_{B}^{A}\right)$, solving for the tax differential $\left(t_{A}-t_{B}\right)$ and choosing the larger of the two solutions to the quadratic equation yields

$$
\left(t_{A}-t_{B}\right)^{H}=\frac{(3 \sqrt{6}-17)(2 \alpha-2 \bar{w}-\tau)^{2}}{1152 \beta} .
$$

This is unambiguously negative, as is eq. (13) in the main text for $n=0.5$. To get country $B$ 's best offer $\left(t_{B}^{o}\right)$ we use $(17 \mathrm{~b})$, taking account of the changed quantities in the model with trade and equate the welfare levels in the cases where country $B$ hosts the firm and where it does not $\left(U_{B}^{A}=U_{B}^{B}\right)$. In the presence of trade with country $A$, country $B$ 's welfare depends on the trade union's optimally chosen wage in both regimes, and hence also on $t_{A}$. Country $B$ 's government anticipates the wages that the union in country $A$ will set in each regime [eqs. (A.2) and (A.3)] and it also accounts for the fact that country $A$ 's government sets taxes according to (A.4) in order to minimise the union's surplus. Using this information, country $B$ 's best offer is

$$
t_{B}^{o}=\frac{4(47-21 \sqrt{6})(\alpha-\bar{w})^{2}+\tau[(72 \sqrt{6}-572)(\alpha-\bar{w})+(1391-15 \sqrt{6}) \tau]}{4608 \beta} .
$$

From (A.4) and (A.5) we can derive country $A$ 's optimal tax rate $t_{A}^{*}$ :

$$
t_{A}^{*}=-\frac{4(7+3 \sqrt{6})(\alpha-\bar{w})^{2}+\tau[4(25-2 \sqrt{6})(\alpha-\bar{w})-(441-\sqrt{6}) \tau]}{1536 \beta} .
$$

Country $A$ will attract the outside firm in equilibrium, if its welfare in the case where it hosts the firm exceeds its welfare in the case where it does not. Using (17a) to calculate country $A$ 's utility in the two regimes gives

$$
U_{A}^{A}-U_{A}^{B}=\frac{(9 \sqrt{6}-19)(2 \alpha-2 \bar{w}-\tau)^{2}}{2304 \beta}>0
$$

so that country $A$ is indeed better off if it hosts the outside firm. Hence the unionised country will attract the firm in an equilibrium with trade when the two countries are of equal size. This shows that Proposition 2 carries over qualitatively to a scenario 
with trade in good $x$. Moreover it can be shown that, for any non-prohibitive level of $\tau$, (per-capita) welfare in country $A$ is again lower than (per-capita) welfare in country $B$ :

$$
U_{A}^{A}-U_{B}^{A}=-\frac{(2 \alpha-2 \bar{w}-\tau)[2(47-13 \sqrt{6})(\alpha-\bar{w})-(43-11 \sqrt{6}) \tau]}{1536 \beta}<0 .
$$

Hence, for countries of equal size, Proposition 3 also extends to the case where good $x$ is traded between countries $A$ and $B$. 


\section{Literature}

Baldwin, R.E., R. Forslid, P. Martin, G. Ottaviano and F. Robert-Nicoud (2003). Economic geography and public policy. Princeton University Press.

Baldwin, R.E. and P. Krugman (2004). Agglomeration, integration and tax harmonisation. European Economic Review 48, 1-23.

Bjorvatn, K. and C. Eckel (2006). Policy competition for foreign direct investment between asymmetric countries. European Economic Review 50, 1891-1907.

Black, D.A. and W.H. Hoyt (1989). Bidding for firms. American Economic Review 79, $1249-1256$.

Borck, R. and M. Pflüger (2006). Agglomeration and tax competition. European Economic Review 50, 647-668.

Brander, J. and P. Krugman (1983). A 'reciprocal dumping' model of international trade. Journal of International Economics 15, 313-321.

Brander, J. and B. Spencer (1988). Unionized oligopoly and international trade policy. Journal of International Economics 24, 217-234.

Cahuc, P. and A. Zylberberg (2004). Labor Economics. MIT Press, Cambridge, Massachusetts.

Coughlin, C., J. Terza and V. Arromdee (1991). State characteristics and the location of foreign direct investment within the United States. Review of Economics and Statistics 73, 675-682.

Davies, R.B. (2005). State tax competition for foreign direct investment: A winnable war? Journal of International Economics 67, 498-512.

Devereux, M.P., R. Griffith and A. Klemm (2002). Corporate income tax reforms and international tax competition. Economic Policy 35, 451-495.

Driffill, J. and F. van der Ploeg (1995). Trade liberalization with imperfect competition in goods and labour markets. Scandinavian Journal of Economics 97, 223-243. 
Egger, P. and T. Seidel (2007). Tax competition with agglomeration and unemployment. Mimeo, University of Munich and ifo Institute.

Ferrett, B. and I. Wooton (2005). Competing for a Duopoly: International Trade and Tax Competition. CEPR Discussion Paper 5379.

Freeman, R. (2007). Labor market institutions around the world. NBER Working Paper 13242. Washington, D.C.

Fuest, C. and B. Huber (1999). Tax coordination and unemployment. International Tax and Public Finance 6, 7-26.

Fuest, C. and B. Huber (2000). Why do governments subsidise investment and not employment? Journal of Public Economics 78, 171-192.

Haufler, A. and I. Wooton (1999). Country size and tax competition for foreign direct investment. Journal of Public Economics 71, 121-139.

Horstmann, I.J. and J.R. Markusen (1992). Endogenous market structures in international trade (natura facit saltum). Journal of International Economics 32, 109-129.

Huizinga, H. (1993). International market integration and union wage bargaining. Scandinavian Journal of Economics 95, 249-255.

Kind, H.J., K.H. Midelfart Knarvik and G. Schjelderup (2000). Competing for capital in a 'lumpy' world. Journal of Public Economics 78, 253-274.

Leahy, D. and C. Montagna (2000). Unionisation and foreign direct investment: Challenging conventional wisdom? The Economic Journal 110, C80-C92.

Lejour, A.M., and H.A. Verbon. (1996). Capital mobility, wage bargaining, and social insurance policies in an economic union. International Tax and Public Finance 3, $495-513$.

Lommerud, K.E., F. Meland and L. Sørgard (2003). Unionised oligopoly, trade liberalisation and location choice. The Economic Journal 113, 782-800. 
Mezzetti, C. and E. Dinopoulos (1991). Domestic unionization and import competition. Journal of International Economics 31, 79-100.

Mukherjee, A. (2008). Unionised labour market and strategic production decision of a multinational. The Economic Journal, forthcoming.

Munch, J.R. (2003). The location of firms in unionized countries. Scandinavian Journal of Economics 105, 49-71.

Naylor, R. (1998). International trade and economic integration when labour markets are generally unionised. European Economic Review 42, 1251-1267.

Naylor, R. and M. Santoni (2003). Foreign direct investment and wage bargaining. Journal of International Trade and Economic Development 12, 1-18.

OECD (2008). OECD Factbook 2008. Online version at http://dx.doi.org/10.1787/267402482548.

Oswald, A.J. (1993). Efficient contracts are on the labour demand curve. Theory and facts. Labour Economics 1, 85-113.

Ottaviano G. and T. van Ypersele (2005). Market size and tax competition. Journal of International Economics 67, 25-46.

Skaksen, M. R. (2005). Should governments subsidise inward foreign direct investment? Scandinavian Journal of Economics 10\%, 123-140. 